\title{
O PROCESSO DE COMUNICAÇÃO CONTÁBIL NO SETOR PÚBLICO: PERCEPÇÃO DOS CONTADORES SOBRE UNIVERSIDADES FEDERAIS
}

THE ACCOUNTING COMMUNICATION PROCESS AT THE PUBLIC SECTOR: ACCOUNTANT'S PERCEPTION OVER FEDERAL UNIVERSITIES

EL PROCEDIMIENTO DE COMUNICACIÓN CONTABLE EN EL SECTOR PÚBLICO: PERCEPCIÓN DE LOS CONTADORES SOBRE UNIVERSIDADES FEDERALES

Autores

Diego Messias

Mestre em Contabilidade pela Universidade Estadual do Oeste do Paraná (UNIOESTE).

Contador da Universidade Federal da Integração Latino-Americana (UNILA). Endereço: Avenida Gramado, 2250, Jardim Canadá, CEP: 85869-183, Foz do Iguaçu, Paraná - Brasil. Telefone: 45 98432-3576.

Identificadores (ID): Lattes: http://lattes.cnpq.br/1329033661462930 ORCID: http://orcid.org/0000-0003-3927-0246 Research Gate: www.researchgate.net/profile/Diego_Messias2 E-mail: diegomessias.1986@gmail.com

Silvana Anita Walter Doutora em Administração (PUC/PR). Docente da Universidade Estadual do Oeste do Paraná (UNIOESTE). Professora no Curso de Administração e do Mestrado Profissional em Administração da Universidade Estadual do Oeste do Paraná (UNIOESTE). Endereço: Rua Pernambuco, 1777, Centro, CEP: 85960-000, Marechal Cândido Rondon, Paraná - Brasil. Telefone: 45 99955-2548. Identificadores (ID): Lattes: http://lattes.cnpq.br/6055446867536139 ORCID: http://orcid.org/0000-0003-1684-5465 


\title{
RESUMO
}

Este estudo objetivou verificar como os contadores responsáveis pela elaboração dos relatórios contábeis percebem o processo de construção da informação contábil em quatro universidades federais. A análise sustenta-se nas teorias da Comunicação e da Semiótica. Procederam-se entrevistas em profundidade com os contadores de quatro universidades federais e empregou-se análise do discurso francesa. Entre os resultados, identificou-se que os processos formais são percebidos muitas vezes como uma obrigatoriedade; que os processos de conferência apontam para desvios das atividades dos contadores; e que são poucas as demandas por informações contábeis. No tocante à interpretação das informações, os contadores destacaram a necessidade de compreender previamente as finalidades dos usuários; que a linguagem contábil tem de ser adequada ao perfil do usuário demandante; e que buscam revisar os relatórios quanto à manutenção da lógica das informações prestadas. Conclui-se que os participantes percebem que o processo de construção da informação contábil apresenta muitas lacunas e incogruências que vão de encontro aos cuidados adotados por eles em relação à interpretação das informações contábeis.

Palavras chave: Contabilidade. Teoria da Comunicação. Semiótica. Análise do Discurso.

\begin{abstract}
This study aimed to verify how the accountants responsible for preparing the accounting reports perceive the process of construction of accounting information in four federal universities. The analysis is based on Communication and Semiotics theories. In-depth interviews were realized with the accountants of four federal universities and the french discourse analysis was utilized. Among the results, it was identified that formal processes are often perceived as an obligation; That the conference processes point to deviations from the activities of accountants; And that there are few demands for accounting information. Regarding the interpretation of the information, the accountants emphasized the need to understand previously the purposes of the users; That the accounting language must be adequate to the profile of the plaintiff; And that seek to review the reports regarding the maintenance of the logic of the provided information. It is concluded that participants perceive that construction process of the accounting information presents many gaps and inconsistencies that go against the care they take in relation to the interpretation of the accounting information.
\end{abstract}

Keywords: Accounting. Communication Theory. Semiotics. Discourse Analysis

\section{RESUMEN}

Este estudio tuvo como objetivo verificar cómo los contadores responsables por la elaboración de los informes contables perciben el proceso de construcción de la información contable en cuatro universidades federales. El análisis se sustenta en las teorías de la Comunicación y de la Semiótica. Se realizaron entrevistas en profundidad con los contadores de cuatro universidades federales y se empleó análisis del discurso francés. Entre los resultados, se identificó que los procesos formales son percibidos muchas veces como una obligatoriedad; Que los procesos de conferencia apuntan a desviaciones de las actividades de los contadores; y que son pocas las demandas de información contable. En cuanto a la interpretación de las informaciones, los contadores destacaron la necesidad de comprender previamente las finalidades de los usuarios; que el lenguaje contable debe ser adecuado al

Revista Ambiente Contábil - ISSN 2176-9036 - UFRN - Natal-RN. v. 10. n. 1, p. 37 - 53, jan./jun. 2018. 
perfil del usuario demandante; y que buscan revisar los informes sobre el mantenimiento de la lógica de la información proporcionada. Se concluye que los participantes perciben que el proceso de construcción de la información contable presenta muchas lagunas e incógnitas que van en contra de los cuidados adoptados por ellos en relación a la interpretación de las informaciones contables.

Palabras clave: Contabilidad. Teoría de la Comunicación. Semiótica. Análisis del Discurso.

\section{INTRODUÇÃO}

A Contabilidade origina-se da relação entre a captação e processamento dos fatos econômico-financeiros que impactam as riquezas das organizações, de acordo com paradigmas e metodologias próprias, e a comunicação desses fatos a agentes interessados em conhece-los. Como ensinado por Iudícibus, Martins e Carvalho (2005), a Contabilidade tem o desafio de capturar a ocorrência dos eventos econômicos, precifica-los e comunicar seus efeitos sobre o patrimônio aos usuários.

Para atingir sua finalidade de maneira eficiente, todo o processo contábil, que se inicia na ocasião dos fatos econômicos e se encerra na compreensão dos reflexos desses fatos pelos usuários, necessita ser pensado criticamente e planejado. Que tipo de fato ocorreu? Como medi-lo? A quem interessa? Como e quando transmitir? Perguntas como essas devem ser consideradas pelo contador para atribuir qualidade à informação contábil, uma vez que a Contabilidade somente cumpre seu papel se o destinatário/usuário da informação contábil a compreende efetivamente.

Nessa linha de raciocínio, a Contabilidade pode ser compreendida como um processo de comunicação entre o profissional contábil e o usuário final da informação, seja ele interno ou externo à organização. Dessa forma, teorias relacionadas aos estudos da linguagem e da comunicação são bem-vindas ao campo de estudo da Contabilidade, ao possibilitarem a análise e melhoria do processo reconhecimento, mensuração e evidenciação contábil.

Partindo deste ponto de vista, Bedford e Baladouni (1962) desenvolveram um modelo de descrição e avaliação do processo contábil de acordo com os preceitos da Teoria da Comunicação de Claude E. Shannon. Segundo os autores, a referida teoria já vinha sendo introduzida com sucesso em outros ramos do conhecimento como a psicologia experimental, a linguística e a biofísica, e, considerando o fluxo contábil como um processo, perceberam a relevância de se desenvolver estudos com esta abordagem.

Além dos elementos e dimensões do processo contábil, o sentido e significado dos termos e expressões utilizadas pelos contadores vem sendo objeto frequente de estudos. Hendriksen e Van Breda (1999) destacam, nessa linha, que a Contabilidade se caracteriza, entre outras, como uma linguagem aplicada ao mundo dos negócios. Ao resgatarem os conceitos de semântica, sintaxe e pragmatismo da Semiótica, os autores também ressaltam a relevância da interpretação adequada das informações pelos usuários e resgatam frequentes problemas de compreensão dos termos empregados.

Considerando as características qualitativas que devem estar presentes em toda informação contábil, conforme preconizado pela doutrina e pelos normativos - como exemplo cita-se a Estrutura Conceitual Básica - e os aspectos convencionados pelas teorias da

Revista Ambiente Contábil - ISSN 2176-9036 - UFRN - Natal-RN. v. 10. n. 1, p. 37 - 53, jan./jun. 2018. 
Diego Messias e Silvana Anita Walter

Comunicação e da Semiótica e abordados por diversos estudos nas últimas décadas (OLIVER, 1974; BELKAOUI, 1980; DIAS FILHO; NAKAGAWA, 2001; VALENTE, 2014), fica evidenciada a necessidade do desenvolvimento de pesquisas empíricas acerca da comunicação contábil.

A informação contábil inerente à atividade pública se apresenta como uma representativa lacuna de investigação, devido a relevância que apresenta para a gestão das instituições e da coisa pública, que, por sua vez, refletem diretamente nos serviços postos à disposição da sociedade.

A Contabilidade Aplicada ao Setor Público apresenta divergências metodológicas e de aplicabilidade em relação à vertente empresarial, todavia a essência da ciência permanece inalterada, assim como sua finalidade de fornecer subsídios sólidos ao processo decisório. Assim sendo, a abordagem do processo contábil sob a ótica das Teorias da Comunicação, proposta por Bedford e Baladouni (1962), e da Semiótica é igualmente aplicável ao setor público.

As instituições federais de ensino superior, autarquias e fundações vinculadas ao Ministério da Educação, se apresentam como um campo frutífero para estudos acerca do processo de comunicação contábil, em virtude do grande volume de recursos geridos, da autonomia que dispõe quanto a sua gestão e dos reflexos sociais por elas proporcionados.

Estudos recentes como os de Dias Filho e Nakagawa (2001), Nakagawa e Dias Filho (2002), Iudícibus, Martins e Carvalho (2005), Lopes, Ribeiro e Cavalcante (2009), Silva e Novais (2013), Dias Filho (2013), entre outros, abordaram a relação entre a Contabilidade e as Teorias da Comunicação e da Semiótica de forma teórica, procedendo ensaios e discussões acerca dos postulados.

Abordagens empíricas foram realizadas nos estudos de Oliver (1974) e Belkaoui (1980), onde buscou-se identificar as interpretações de profissionais, estudantes e outros grupos acerca de termos contábeis. As pesquisas, que se deram por abordagens quantitativas, possibilitaram conclusões limitadas acerca das questões levantadas.

Diante do apresentado, ressalta-se como lacuna a realização de estudos qualitativos e detalhados acerca de casos específicos, de forma a mapear e avaliar todo o papel de planejamento, construção e interpretação da informação contábil, sobretudo no setor público, sob à luz das Teorias da Comunicação e da Semiótica. Neste contexto, emerge a seguinte questão: Qual a percepção dos contadores sobre o processo de construção da informação contábil no setor público?

Para responder a questão de pesquisa, objetiva-se verificar como os contadores responsáveis pela elaboração dos relatórios contábeis percebem o processo de construção da informação contábil em quatro universidades federais. A análise sustenta-se nos aspectos e dimensões das teorias da Comunicação e da Semiótica.

Espera-se que os resultados da pesquisa possam subsidiar melhorias no processo de comunicação contábil nas instituições federais de ensino superior, tendo em vista o contexto analisado e os ruídos identificados. Da mesma forma, outras instituições públicas de ensino superior também podem se utilizar dos achados para repensar a produção e utilização das informações contábeis em seus processos de gestão. Ademais, os resultados podem ser

Revista Ambiente Contábil - ISSN 2176-9036 - UFRN - Natal-RN. v. 10. n. 1, p. 37 - 53, jan./jun. 2018. 
aproveitados, parcial ou totalmente, pelas demais instituições que compõe a administração pública, uma vez que o modelo de gestão apresenta similaridades entre os órgãos.

Além desta introdução, o trabalho está estruturado por uma seção de revisão da literatura, onde são resgatados trabalhos reconhecidos na área. Na sequência é apresentada uma descrição dos procedimentos metodológicos. Na sequência são abordadas e analisadas as dissertações e teses localizadas na busca. Ao final são apresentadas as principais conclusões e considerações finais.

\section{REVISÃO DA LITERATURA}

\subsection{INFORMAÇÃO CONTÁBIL}

A informação contábil se constitui como o principal produto da atividade contábil, e por esta razão tem de atender a padrões elevados de qualidade, sob pena de inviabilizar o atingimento das finalidades da Contabilidade. Tais padrões, designados como características qualitativas da informação contábil, podem ser interpretados como propriedades que indispensáveis para torna-las úteis ao processo de tomada de decisão (HENDRIKSEN; VAN BREDA, 1999).

Entre outros pronunciamentos e orientações de entidades voltadas ao desenvolvimento da Contabilidade em âmbito internacional, o Financial Accounting Standards Board (FASB) por meio do Statement of Financial Accounting Concepts (SFAC) $\mathrm{n}^{\mathrm{o}} 2$, organizou as características qualitativas da informação contábil, apresentando-as de forma sistematizada e demonstrando o seu encadeamento e interdependência.

Ao elencar as características qualitativas, o FASB procedeu uma distinção entre específicas para usuários e específicas para a tomada de decisões, de forma a facilitar a compreensão do leitor quanto a aplicabilidade de cada uma, bem como sua relação com o produto final e com a finalidade do processo. Hendriksen e Van Breda (1999) citam como exemplo o fato de usuários sofisticados poderem considerar alguma informação irrelevante porque já a conhecem, ao mesmo tempo que veem informações complexas como mais relevantes. Por outro lado, usuários novatos apenas compreenderiam informações simplificadas. Como destacado pelos autores, a natureza do usuário é um fator determinante para a decisão a respeito da forma e tipo da informação a ser divulgada.

Revista Ambiente Contábil - ISSN 2176-9036 - UFRN - Natal-RN. v. 10. n. 1, p. 37 - 53, jan./jun. 2018. 
Figura 1 - Hierarquia das qualidades da informação contábil

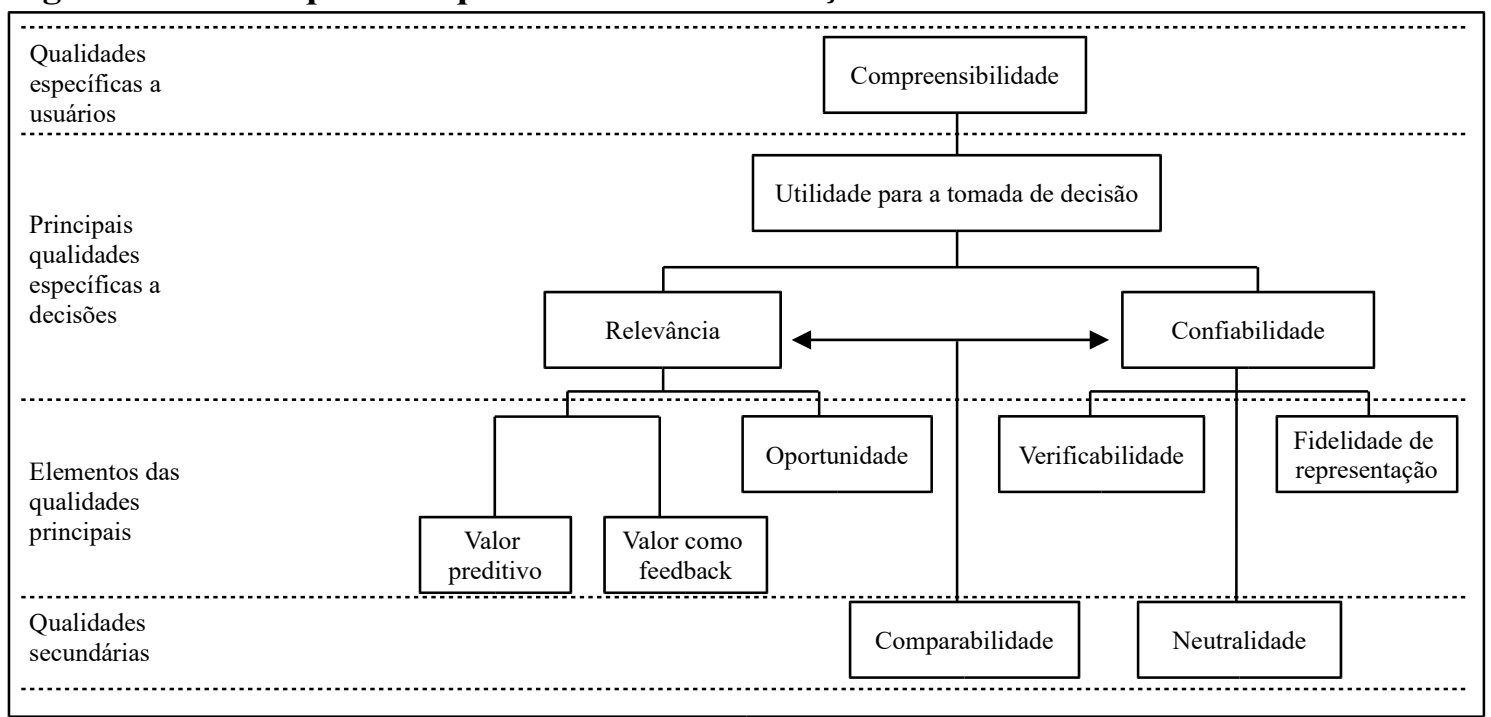

Fonte: adaptado de FASB (1980).

Fica evidenciado no esquema apresentado na Figura 1 a hierarquia existente entre as características qualitativas da informação, seus elementos componentes (valor preditivo, valor de feedback, oportunidade, verificabilidade e fidedignidade) e as características secundárias (comparabilidade e neutralidade). Em outros termos, é necessário que a informação seja comparável e neutra (qualidades secundárias) e contenha os elementos de relevância e confiabilidade (necessários à decisão) para que supra o usuário interno ou externo de maneira satisfatória.

Nesse contexto de construção de uma informação direcionada a um ouvinte específico (usuário), com componentes constituintes necessários (características qualitativas) e que segue um encadeamento lógico (fluxo), a Contabilidade pode ser vista como um processo de comunicação, como defendido por Bedford e Baladouni (1962) e Dias Filho e Nakagawa (2001), e, nesse sentido, ser estudada sob a ótica de teorias voltadas à comunicação e linguagem interpessoal como as Teorias da Comunicação e da Semiótica.

\subsection{TEORIA DA COMUNICAÇÃO}

A comunicação, de maneira bastante simplória, pode ser compreendida como a ação de se transmitir e receber uma mensagem (BERLO, 1999). É um fluxo no qual uma informação é coletada, compreendida, processada e repassada a outro interlocutor de forma codificada, para que este possa também compreendê-la após proceder a decodificação.

Considerando que a comunicação está presente em todas as relações entre os indivíduos, é evidente e plausível que estudos de diversos campos do conhecimento se utilizem de suas bases e preceitos para compreender o comportamento humano naquele ramo, para desenvolvimento da ciência (HAYAKAWA, 1967). 
Figura 2 - Matriz da comunicação contábil

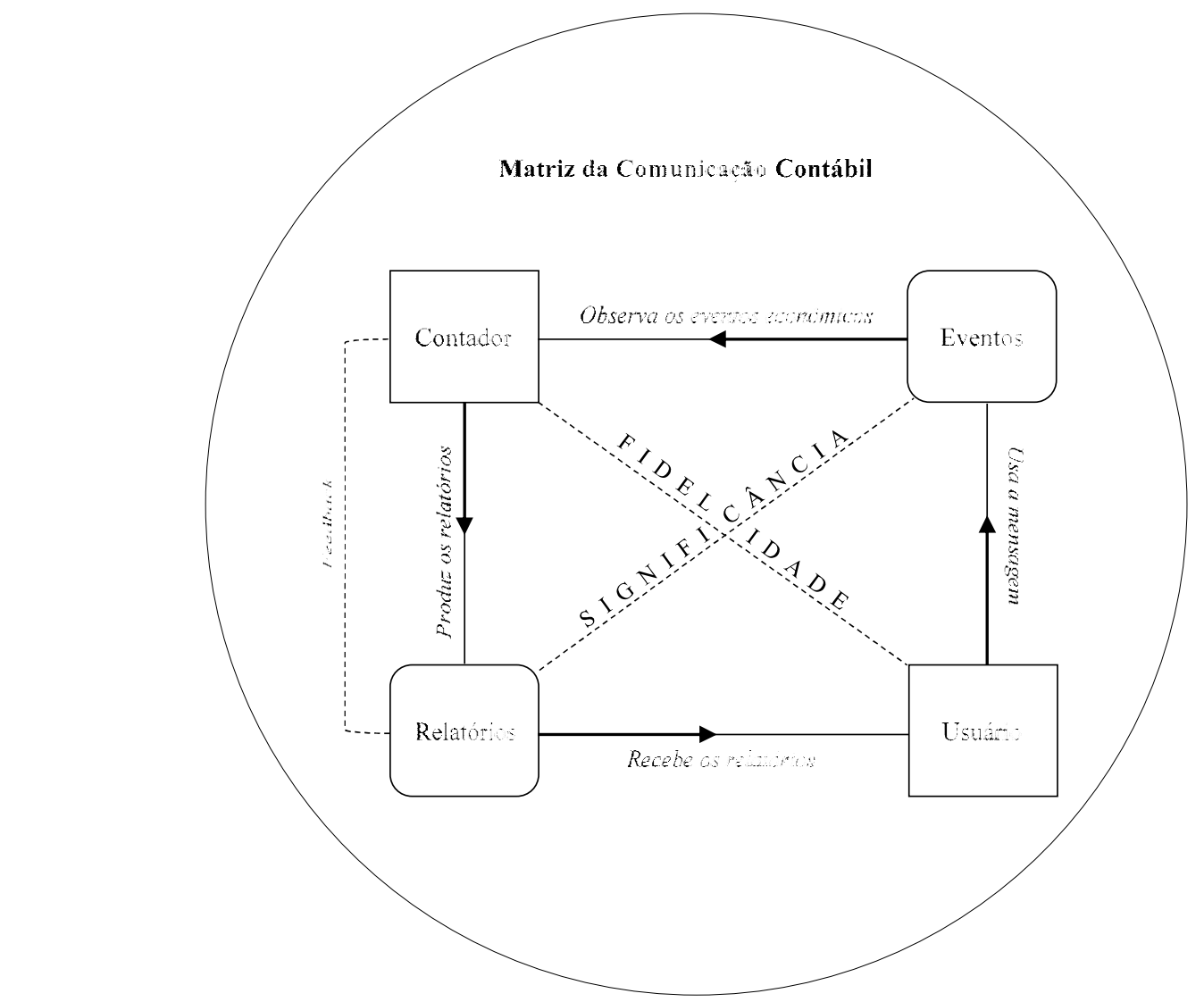

Fonte: Bedford e Baladouni (1962).

Dentro do campo de estudo da Teoria da Comunicação tem-se, dentre outras, que o processo comunicativo é composto por cinco elementos a saber: emissor, mensagem, código, canal e receptor (BERLO, 1999). Essa percepção é oriunda do trabalho de Shannon e Weaver (1949), que, mesmo tendo como objeto de estudo as telecomunicações, estabeleceram esse rol de elementos que são adotados pela maioria maciça das pesquisas na área da comunicação, como percebido por Berlo (1999) e abordado por Bedford e Baladouni (1962).

Resgatando, então, os conceitos da comunicação de Aristóteles e da teoria matemática da comunicação de Shannon e Weaver (1949), Bedford e Baladouni (1962) proporam um modelo de abordagem da Contabilidade sob a ótica da Teoria da Comunicação, onde os indivíduos e as ações do processo foram segregados e analisados individualmente, de forma a possibilitar a identificação dos problemas inerentes ao processo. Segundo os autores, a interpretação e análise da Contabilidade como um sistema de comunicação pode fornecer uma imagem mais clara de sua função no sistema da macroeconomia.

Nesta análise, os autores vislumbraram o processo contábil, sob a ótica da Teoria da Comunicação, é composto por quatro elementos: os eventos econômicos, o contador, os relatórios contábeis e o usuário da informação. O referido modelo incorpora, ainda, conceitos de fidelidade e significância, com o objetivo de caracterizar a relação desejada entre o contador e o usuário e a relação entre os demonstrativos contábeis e os eventos econômicos

Revista Ambiente Contábil - ISSN 2176-9036 - UFRN - Natal-RN. v. 10. n. 1, p. 37 - 53, jan./jun. 2018. 
(DIAS FILHO; NAKAGAWA, 2012).

A significância abordada pelos autores refere-se ao grau de relevância e adequação com que os fatos econômicos são descritos pelas atividades de Contabilidade. Como defendido por Valente (2014), a preocupação com as reais necessidades do usuário final da informação contábil, deve ser um princípio orientador e balizador do contador.

A fidelidade por sua vez se refere à correspondência que deve existir entre os significados que o usuário atribui às mensagens e aqueles que o contador pretende transmitir. Esse atributo se relaciona primordialmente com o emissor da comunicação (no caso da Contabilidade, o contador), onde se faz necessário estudo aprofundado acerca das terminologias utilizadas e sua adequação com perfil do usuário. Complexidade e finalidade são pontos fundamentais a serem considerados (BERLO, 1999).

Como ressaltado por Dias Filho e Nakagawa (2001) são muitos os estudos que indicam problemas quanto a compreensibilidade das informações e dos relatórios contábeis, em virtude das terminologias empregadas em sua construção, geralmente em desacordo com o perfil do usuário. Problemas como esses, presentes no elemento "mensagem", são também objeto de estudo de ciências vinculadas às linguagens, como a Semiótica, onde se busca otimizar a compreensão do receptor da comunicação.

A percepção da contabilidade como uma forma de linguagem parte do pressuposto que, antes, se configura como um processo de comunicação. $\mathrm{O}$ uso de termos técnicos para composição de mensagens também fundamenta a visão da contabilidade como uma linguagem (NAKAGAWA; DIAS FILHO, 2002). Sob esse prisma, Hendriksen e Van Breda (1999) lembram que ao se elaborar informações contábeis devem ser respondidas questões como:

- Que efeito as palavras utilizadas pela contabilidade terão sobre os usuários da informação?

- Que significado tais palavras terão para eles, se houver algum?

- As palavras se conectam e tem sentido lógico?

As questões acima estão ligadas diretamente com o estudo das linguagens. A Semiótica pode ser compreendida como a ciência de todas as linguagens, que fornece recursos metodológicos para facilitar a compreensão dos fenômenos que tocam a consciência humana (MORRIS, 1976). Ela aborda as linguagens sob três níveis a saber: sintático, semântico e pragmático. No nível sintático busca-se compreender as informações contábeis em relação ao conjunto de normas e princípios que regem a sua elaboração (sentido lógico). Já no nível semântico a preocupação está na compreensão da informação pelo receptor com o significado pretendido pelo emissor. Por fim, no nível pragmático a atenção está nos efeitos da comunicação, ou seja, se a informação atende a necessidades do demandante. Cada uma das questões acima se relaciona com um dos níveis da Semiótica.

Em análise às características qualitativas da informação contábil tratadas no SFAC 2 do FASB, percebe-se que a compreensibilidade se encontra no topo hierárquico das

Revista Ambiente Contábil - ISSN 2176-9036 - UFRN - Natal-RN. v. 10. n. 1, p. 37 - 53, jan./jun. 2018. 
qualidades necessárias. O FASB (1980) destaca também que o grau de fídelidade da representação contábil depende em muito do significado das palavras utilizadas no processo de evidenciação. Nesse sentido, verifica-se a relação da Contabilidade com a Semiótica, uma vez que se utilizam de diversos signos com o objetivo de informar. Mason e Swanson (1981) reforçam essa ideia, ao exemplificar a mensuração contábil como um signo quantitativo acerca dos eventos econômicos.

Assim sendo, a Semiótica, como ciência dedicada ao estudo dos signos, pode contribuir para aprimorar a Contabilidade à medida que nos conduza a uma melhor percepção dos eventos econômicos que impactam o desempenho das organizações (DIAS FILHO; NAKAGAWA, 2012). Pode oferecer, segundo Nakagawa e Pretto (2000), instrumental metodológico para auxiliar na identificação, observação e análise dos fenômenos que provocam as variações patrimoniais.

\section{PROCEDIMENTOS METODOLÓGICOS}

\subsection{CARACTERIZAÇÃO DA PESQUISA}

De forma a atingir o objetivo estabelecido, realizaram-se entrevistas semiestruturadas com os contadores - que se caracterizam como os responsáveis pela construção das informações e dos relatórios contábeis - de quatro universidades federais, quais sejam: Universidade Federal do Rio de Janeiro (UFRJ), Universidade de Brasília (UnB), Universidade do Rio Grande do Norte (UFRN) e Universidade Federal do Pará (UFPA). Como diversos contadores atuam nos departamentos contábeis das universidades participantes do estudo, optou-se por entrevistar o chefe do setor que, pela função ocupada, representa o departamento como um todo.

Os sujeitos da pesquisa são originários de instituições localizadas em distintas regiões do território nacional. A única região brasileira que não está representada no estudo é o Sul, uma vez que não se obteve êxito quando do contato com os contadores das universidades da região para agendamento da coleta.

Os dados foram coletados por meio de entrevistas semiestruturadas por serem uma forma poderosa para se obter informações mais profundas e amplas acerca do tema pesquisado (KERLINGER, 1996). As entrevistas foram realizadas via ligações telefônicas, devidamente gravadas com o consentimento dos participantes para posterior transcrição. $\mathrm{O}$ roteiro de entrevista foi constituído com base nas teorias que sustentam o estudo (Comunicação e Semiótica), sendo segregado como apresentado no Quadro 1.

Revista Ambiente Contábil - ISSN 2176-9036 - UFRN - Natal-RN. v. 10. n. 1, p. 37 - 53, jan./jun. 2018. 
Quadro 1 - Construtos da pesquisa

\begin{tabular}{|c|c|c|c|c|}
\hline Teoria de base & Construto & Dimensões & Categorias de Análise & Autores \\
\hline \multirow{5}{*}{$\begin{array}{c}\text { Teoria da } \\
\text { Comunicação }\end{array}$} & \multirow{5}{*}{$\begin{array}{c}\text { Processo de } \\
\text { comunicação contábil }\end{array}$} & \multirow{3}{*}{ Observação } & Recebimento & \multirow{5}{*}{$\begin{array}{l}\text { (Shannon \& Weaver, 1949) } \\
\text { (Bedford \& Baladouni, 1962) }\end{array}$} \\
\hline & & & Interpretação & \\
\hline & & & Seleção & \\
\hline & & \multirow{2}{*}{ Produção } & Codificação & \\
\hline & & & Transmissão & \\
\hline \multirow{3}{*}{ Semiótica } & \multirow{3}{*}{$\begin{array}{c}\text { Interpretação das } \\
\text { informações contábeis }\end{array}$} & Sintático & Estrutura & \multirow{3}{*}{$\begin{array}{l}\text { (Belkaoui, 1980) } \\
\text { (Oliver, 1974) }\end{array}$} \\
\hline & & Semântico & Compreensão & \\
\hline & & Pragmático & Utilização & \\
\hline
\end{tabular}

Fonte: Elaborado pelos autores.

\subsection{TÉCNICA DE ANÁLISE E INTERPRETAÇÃO DOS DADOS}

Os dados coletados foram processados por meio da versão 7 do software Atlas.ti ${ }^{\circledR}$. Como metodologia de análise das entrevistas, optou-se pela análise do discurso de abordagem francesa, seguindo os preceitos e orientações de Orlandi (1999). A escolha se justifica pela necessidade de captação de informações não verbalizadas pelos respondentes, que são de relevância ímpar para compreensão efetiva do processo de construção da informação contábil, bem como dos fatores que são considerados pelos responsáveis pela elaboração. Foram analisados os conceitos de dito e não-dito de Orlandi (1999).

A metodologia da análise do discurso se justifica, também, pela natureza da teoria sustentadora da pesquisa (Semiótica), que se dedica a estudos sobre a linguagem. Como o método examina o que fica de fora da linguagem falada, possibilitará a compreensão mais acurada do dito pelo entrevistado.

\section{APRESENTAÇÃO E ANÁLISE DOS DADOS}

Nesta seção são apresentados, de forma sistematizada, os dados coletados por meio das entrevistas, de forma a demonstrar o processo de construção da informação contábil em instituições públicas sob a perspectiva dos contadores. Na sequência apresenta-se uma análise do dito pelos respondentes, de forma a compreender fatores e conceitos não ditos quando das entrevistas.

A coleta dos dados foi dividida em dois blocos temáticos: processo de comunicação contábil e interpretação das informações contábeis, em setembro de 2016.

\subsection{PROCESSO DE COMUNICAÇÃO CONTÁBIL}

No primeiro bloco, buscou-se compreender todo o processo de comunicação da informação contábil nas universidades federais, partindo desde a ocorrência dos fatos econômicos, sua observação, processamento, produção, codificação, transmissão e recepção. Todas essas etapas foram divididas em duas dimensões estabelecidas por Bedford e Baladouni (1962) e corroboradas por Dias Filho e Nakagawa (2001): observação e produção. 
Segundo Dias Filho e Nakagawa (2001), a observação é constituída das seguintes etapas: recebimento de informações sobre os eventos econômicos da empresa, interpretação dessas informações e seleção daquela que deverá ser comunicada. Já a dimensão da produção se caracteriza por envolver as seguintes atividades: codificação da informação e transmissão desta para o usuário final.

Os contadores das universidades federais foram provocados, por meio de quatorze questões, a descrever os passos adotados na coleta das informações que são utilizadas na produção, além de processos e fatores considerados na elaboração dos relatórios contábeis. Considerando que há relatórios que tem forma, conteúdo e linguagem definidos normativamente, não permitindo adaptações por parte dos contadores, os entrevistados foram informados que as questões se referiam apenas a demonstrativos demandados internamente e, por este motivo, não terem que seguir quaisquer padrões. Nesse tipo de relatório prevalecem os conceitos e concepções dos contadores, por terem total discricionariedade em sua elaboração. Na Figura 3 são demonstradas as principais citações dos respondentes acerca do processo de comunicação contábil, nas dimensões da observação e da produção.

Quanto à dimensão da observação, percebe-se que as informações são repassadas aos setores de contabilidade por meio de processo (sentido estrito) formalizado. Os respondentes entendem que a adoção de processos formais para a coleta de dados se configura como uma rotina própria dos setores de contabilidade e que dá garantias de fidedignidade e responsabilidade aos contadores. Todavia, como discurso não-dito está a obrigatoriedade na administração pública da utilização de processos, físicos ou virtuais, para quaisquer tramitações. Dessa forma, não necessariamente os processos se configuram como uma forma de otimização das atividades contábeis, mas podem ser, todavia, apenas uma obrigatoriedade inerente à atividade contábil na esfera pública.

No tocante a fidedignidade dos dados utilizados na produção dos relatórios contábeis, questionou-se os contadores sobre procedimentos de conferência e/ou validação das informações recebidas. Todos os respondentes afirmaram que adotam procedimentos de validação, todavia, ao descreverem as práticas, evidenciou-se que se trata de conferência dos documentos juntados aos autos, de caráter fiscalizatório e não contábil. Pelo dito, são adotados mecanismos de conferência dos fatos econômicos que impactaram no patrimônio do ente estatal, pelo não-dito percebe-se desvios das atividades dos contadores atuantes na administração pública, em virtude, possivelmente, das atuações e autuações dos órgãos de controle interno e externo que acabam por atribuir aos setores contábeis funções de controle setorial. 


\section{Figura 3 - Processo de comunicação contábil (Teoria da Comunicação)}

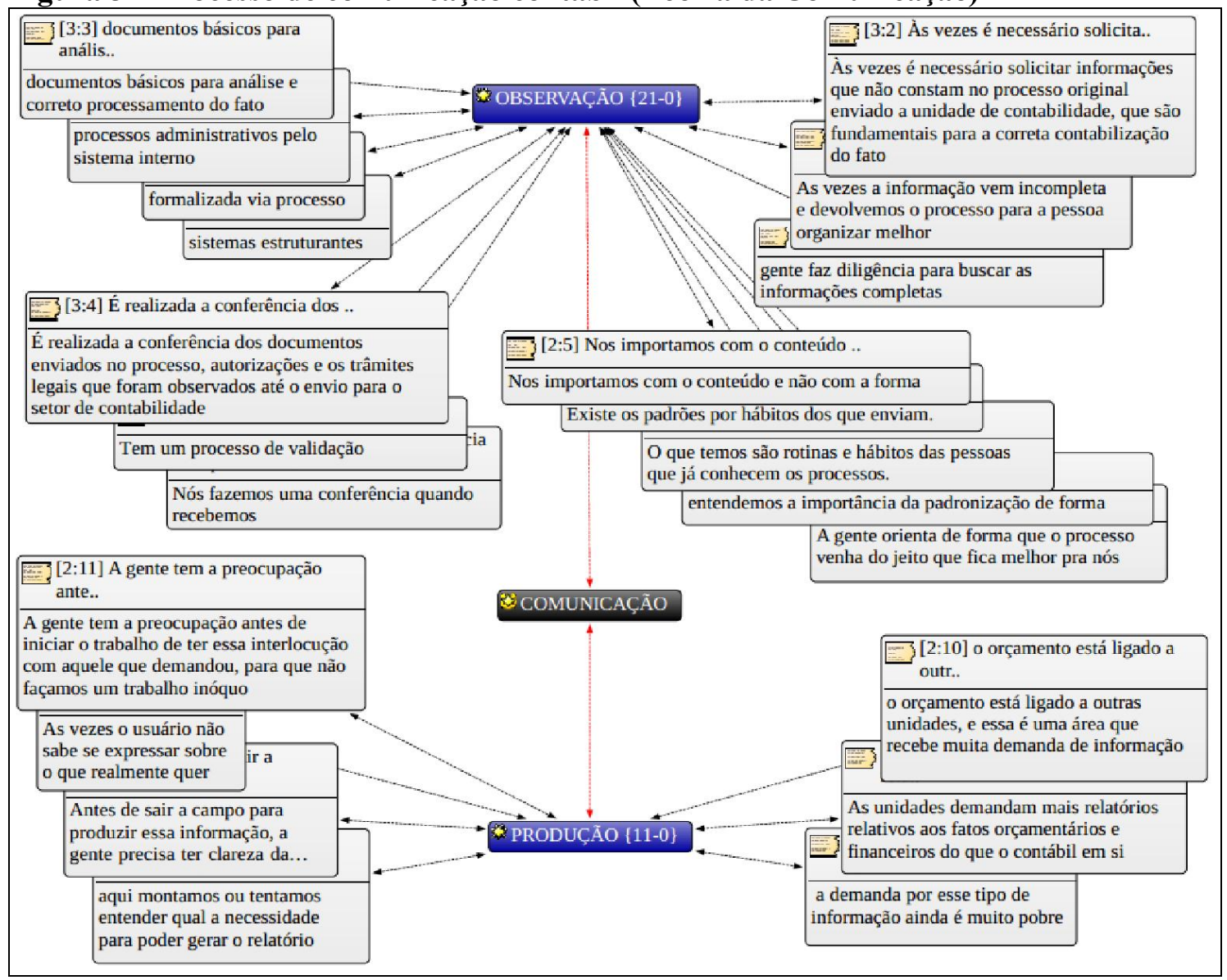

Fonte: Dados da pesquisa.

Ainda na dimensão da observação buscou-se captar a adoção de padrões de forma das informações recebidas, de forma a otimizar o processo de interpretação e processamento. As respostas giraram em torno da não padronização, nem mesmo dentro de cada instituição. Os hábitos e as rotinas, utilizadas pelas diversas unidades que suprem os setores de contabilidade com informações, se sobresaem em relação as necessidades de padronização. Argumentos como "nos importamos com o conteúdo e não com a forma" e "entendemos a importância da padronização de forma" se contradizem e demonstrarm divergências entre os ditos. Quando consideradas as diversidades e o volume de informações tratadas em entidades públicas, fica evidenciada a necessidade de padronização, não dita por alguns dos respondentes.

Passando a dimensão da produção, buscou-se a percepção dos contadores quanto as demandas de relatórios específicos encaminhados aos setores contábeis e quanto a procedimentos adotados antes da produção dos demonstrativos. Foi amplamente citado pelos respondentes que a grande maioria, quase que absoluta, das demandas por informações se concentra no orçamento público. Os contadores afirmam que são raras as demandas por informações de natureza contábil propriamente dita. Argumentos como "as unidades demandam mais relatórios relativos aos fatos orçamentários e financeiros do que o contábil 
em si" e "a demanda por esse tipo de informação ainda é muito pobre" se direcionam a um contexto de que o orçamento público não é contemplado pela contabilidade. Entretanto, devido a natureza da atividade pública, o orçamento é indissociável ao patrimônio da instituição e, por este motivo, faz parte do escopo da contabilidade.

Com relação aos procedimentos prévios a produção, os contadores demonstraram preocupação com a correta identificação das necessidades do demandante antes da produção da informação contábil. Trechos como "antes de sair a campo para produzir essa informação, a gente precisa ter clareza da necessidade do usuário" corrobora a cautela, assim como "o que ele quer, o que ele pretende e pra que ele quer".

Restou evidenciado que o processo de construção da informação contábil no setor público alinha-se ao modelo de processo de comunicação de Shannon e Weaver (1949) e também a abordagem de Bedford e Baladouni (1962), uma vez que apresenta os elementos fundamentais (emissor, mensagem, código, canal e receptor). Alguns pontos do fluxo se diferenciam, todavia, da vertente empresarial da contabilidade, em virtude das particularidades inerentes a atividade pública, como a excessiva normatização e o orçamento público como gerador da maioria dos fatos contábeis.

\subsection{INTERPRETAÇÃO DAS INFORMAÇÕES CONTÁBEIS}

No segundo bloco de questões, orientado pelos preceitos da Semiótica, pretendeu-se identificar se os contadores levam em consideração, quando do planejamento e produção da informação contábil, fatores inerentes ao usuário demandante. As questões foram agrupadas de acordo com as dimensões da Semiótica: pragmática, semântica e sintética (MORRIS, 1976, HENDRIKSEN; VAN BREDA, 1999).

Os contadores das universidades componentes do estudo foram questionados por meio de nove questões a descrever os fatores considerados para produção da informação (Figura 4). Com relação à dimensão pragmática, que tem como base a utilidade da informação prestada, os contadores destacaram a necessidade de compreender previamente as finalidades dos usuários, para que seja possível modelar as informações de forma a atender plenamente as demandas e evitar esforços da equipe contábil em atividades que não tenham usabilidade posterior. Cita-se como exemplo desse argumento os trechos "temos a preocupação antes de iniciar o trabalho de ter essa interlocução com aquele que demandou, para que não façamos um trabalho inóquo" e "temos que saber o que o cliente quer".

O entendimento da relevância da prática de consulta às reais necessidades do usuário, entretanto, não garante a prática dos contadores. Em alguns trechos da coleta percebe-se a não adoção da prática, o que se caracteriza como um discurso não-dito, mas compreendido nas entrelinhas. São exemplos os recortes: "apenas rodo e passo a como pedido" e "em alguns casos o relatório enviado não é suficiente para atender a demanda da unidade e são realizadas alterações ou enviados relatórios adicionais".

A dimensão semântica, por sua vez, preocupa-se com a as formas e signos de linguagem utilizados no processo de comunicação. Na seara contábil, que por sua natureza é dotada de muitos termos técnicos em sua expressão, faz-se necessário considerar o perfil do usuário da informação para que se façam adequações de forma a ampliar e viabilizar a compreensão pelo receptor (BELKAOUI, 1980). Nesse sentido, os respondentes da pesquisa

Revista Ambiente Contábil - ISSN 2176-9036 - UFRN - Natal-RN. v. 10. n. 1, p. 37 - 53, jan./jun. 2018. 
apresentaram opinião uniforme sob a temática: a linguagem contábil tem de ser adequada de acordo com o perfil do usuário demandante. Confirmam o argumento os trechos:

\footnotetext{
"Não adianta usarmos muitos termos técnicos, porque o usuário pode até ter a impressão de estar entendendo, mas na verdade não está";

"nós buscamos considerar o perfil do usuário para redigir os relatórios de forma que a compreensão seja a maior possível”; e

"os relatórios são acompanhados de um texto que explica, em uma linguagem de melhor compreensão para quem não é da área, todos os pontos que constam no relatório enviado".
}

Um dos respondentes da pesquisa, ressaltou que no setor contábil da instituição que atua tem-se o lema "explique para um leigo: do contabilês para o português". Na instituição citada, segundo o contador, todo e qualquer documento gerado tem sua linguagem adequada de forma a facilitar a compreensão do leitor. Esse ponto, todavia, vai de encontro ao fato de não ser possível a adoção de uma linguagem única e que possibilite a compreensão de todos (MORRIS, 1976; BERLO, 1999). Ademais, as próprias características da atividade pública, amplamente regrada e normatizada, inviabilizam a prática defendida pelo contador.

No tocante à dimensão sintática da Semiótica, que analisa o sentido lógico das informações encadeadas (HENDRIKSEN; VAN BREDA, 1999), os respondentes argumentaram que ao buscarem adequar os relatórios às necessidades dos usuários, buscam revisar os relatórios quanto a manutenção da lógica das informações prestadas.

Em síntese, o contadores apresentaram concordância com os estudos de Belkaoui (1980), Hendriksen e Van Breda (1999), Nakagawa e Pretto (2000) e Dias Filho e Nakagawa (2001), quanto anteriores sobre a necessidade de se investigar o perfil e a finalidade do usuário da informação contábil, de forma a balizar a produção do relatório. 
Figura 4 - Interpretação das informações contábeis (Semiótica)

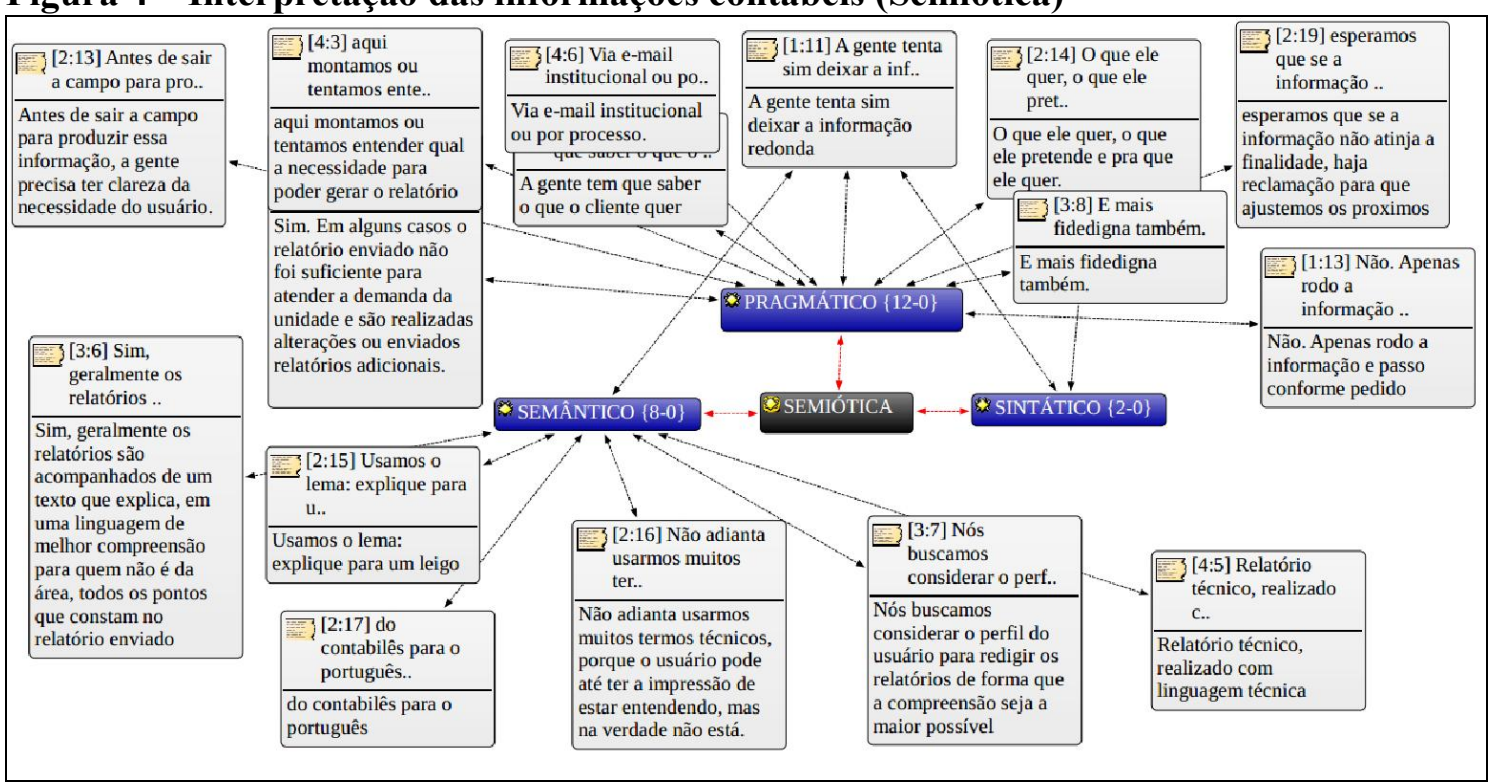

Fonte: Dados da pesquisa.

Por meio do exposto na presente seção, evidenciou-se o processo de construção da informação contábil em quatro universidades federais brasileiras, sob o ponto de vista do contador, produtor da informação. Restou demonstrado os passos adotados na coleta, processamento, produção, codificação, transmissão e recepção da informação, e os fatores considerados quando da construção. A análise do discurso possibilitou a percepção de alguns argumentos não-ditos nas entrevistas, mas que são fundamentais a uma melhor compreensão do processo.

\section{CONSIDERAÇÕES FINAIS}

Objetivou o presente estudo verificar como os contadores responsáveis pela elaboração dos relatórios contábeis percebem o processo de construção da informação contábil em quatro universidades federais. Sustentaram o estudo os preceitos das teorias da Comunicação e da Semiótica, as quais abordam a contabilidade como um processo de comunicação entre contador e usuário e como uma forma de linguagem aplicada ao mundo dos negócios.

Procederam-se entrevistas em profundidade com os contadores de quatro universidades federais brasileiras, distribuídas nas regiões Norte, Nordeste, Sudeste e Centrooeste brasileiros. As respostas obtidas foram abordadas pela metodologia da análise do discurso (vertente francesa), sendo a análise balizada pelo trabalho de Orlandi (1999), onde se pretendeu captar os discursos não-ditos, além dos ditos por meios das respostas.

Entre os resultados sobre o processo de comunicação contábil, identificou-se que os processos formais são percebidos muitas vezes como uma obrigatoriedade e não como uma otimização das atividades contábeis; que os processos de conferência dos fatos econômicos apontam para desvios das atividades dos contadores em virtude, possivelmente, das atuações e

Revista Ambiente Contábil - ISSN 2176-9036 - UFRN - Natal-RN. v. 10. n. 1, p. 37 - 53, jan./jun. 2018. 
autuações dos órgãos de controle interno e externo que acabam por atribuir aos setores contábeis funções de controle setorial; que não há padronização das informações recebidas, nem mesmo dentro de cada instituição; e que a grande maioriadas demandas por informações se concentra no orçamento público, sendo poucas as demandas por informações contábeis.

No tocante à interpretação das informações contábeis, na dimensão pragmática da Semiótica, os contadores destacaram a necessidade de compreender previamente as finalidades dos usuários; na dimensão semântica, referiram que a linguagem contábil tem de ser adequada de acordo com o perfil do usuário demandante; na dimensão sintática, apontaram que buscam revisar os relatórios quanto à manutenção da lógica das informações prestadas. Os respondentes apresentaram maior preocupação com as dimensões pragmática (efeito) e semântica (sentido) da Semiótica.

A partir dos resultados apresentados, conclui-se que os participantes percebem que o processo de construção da informação contábil apresenta muitas lacunas e incogruências (formalidades não-otimizadoras, desvios de atividade, não-padronização das informações recebidas e apresentação de demandas não-contábeis) que vão de encontro aos cuidados adotados por eles em relação à interpretação das informações contábeis (compreender finalidades dos usuários, linguagem adequada ao demandante e revisão dos relatórios). Essas conclusões sugerem um desconhecimento dos usuários e dos demandantes a respeito das contribuições que as informações contábeis podem apresentar e aponta para a necessidade de os contadores atuarem de maneira mais articulada e instrutiva que busquem demonstrar essas possibilidades.

O estudo evidenciou uma visão empírica do processo de construção da informação contábil, possibilitando uma pequena compreensão para essa abordagem científica, uma vez que os estudos que analisam a contabilidade sob a ótica das teorias da Comunicação e da Semiótica, via de regra, se caracterizam como ensaios teóricos. Ademais, outro diferencial da pesquisa é a aplicação em entidades do setor público, que detém diversas características difereciadas à contabilidade aplicada as entidades privadas.

Cita-se como limitação da pesquisa a impossibilidade de triangulação dos dados coletados pelas entrevistas com outras fontes (observação, documentos). Para estudos subsequentes, sugere-se a captação da percepção dos usuários da informação.

\section{REFERÊNCIAS}

BEDFORD, N. M.; BALADOUNI, V. Communication theory approach to accountancy. Accounting Review, v. 37, n. 4, p.650-659, 1962.

BELKAOUI, A. The interprofessional linguistic communication of accounting concepts: an experiment in sociolinguistics. Journal of Accounting Research, p. 362-374, 1980.

BERLO, D. K. O processo da comunicação: introdução à teoria e à prática. 9. ed. São Paulo: Martins Fontes, 1999.

DIAS FILHO, J. M.; NAKAGAWA, M. Análise do processo da comunicação contábil: uma contribuição para a solução de problemas semânticos, utilizando conceitos da teoria da comunicação. Revista Contabilidade \& Finanças, v. 12, n. 26, p. 42-57, 2001.

Revista Ambiente Contábil - ISSN 2176-9036 - UFRN - Natal-RN. v. 10. n. 1, p. 37 - 53, jan./jun. 2018. 
DIAS FILHO, J. M.; NAKAGAWA, M. Reflexões sobre a dimensão semiótica da análise de balanços: uma contribuição à otimização de decisões de crédito. Revista de Contabilidade da UFBA, v. 6, n. 1, p. 33-47, 2012.

FASB. Financial Accounting Standards Board. Statement of Financial Accounting Concepts No. 2. Qualitative Characteristics of Accounting Information. 1980.

HAYAKAWA, S. I. Language in thought and action. 3. ed. New York: Harcourt, Brace Jovanovich, 1967.

HENDRIKSEN, E. S.; VAN BREDA, M. F. Teoria da Contabilidade. São Paulo: Atlas, 1999

IUDÍCIBUS, S. de; MARTINS, E.; CARVALHO, L. N. Contabilidade: aspectos relevantes da epopéia de sua evolução. Revista Contabilidade \& Finanças, v. 16, n. 38, p. 7-19, 2005.

KERLINGER, F. N. Metodologia da pesquisa em Ciências Sociais: um tratamento conceitual. São Paulo: EPU-EDUSP, 1996.

LOPES, J. E. M.; RIBEIRO, R. B.; CAVALCANTE, P. R. N. A Informação Contábil à Luz da Teoria da Comunicação. Revista Ambiente Contábil, v. 1, n. 2, p. 22-37, 2009.

MASON, Richard O.; SWANSON, E. Burton. Measurement for management decision. Addison-Wesley series on decision support. Massachusetts: Addison-Wesley Publishing Company, 1981.

MORRIS, C. W. Fundamentos da teoria dos signos. São Paulo: Ed. da Universidade de São Paulo, 1976.

NAKAGAWA, M.; DIAS FILHO, J. M. A Contabilidade sob o enfoque sociológico: uma abordagem das teorias semióticas e da comunicação. Augusto Guzzo Revista Acadêmica, n. 5, p. 13-22, 2002.

NAKAGAWA, M.; PRETTO, C. B. M. An interdisciplinary view of accountancy in Brazil. In: Asian-Pacific Conference on International Accounting Issues, 12th. Anais. China, 2000.

ORLANDI, E. P. Discurso e leitura. 4. ed. São Paulo: Cortez, 1999.

SOUSA, R. G.; VASCONCELOS, A. F.; CANECA, R. L.; NIYAMA, J. K. O regime de competência no setor público brasileiro: uma pesquisa empírica sobre a utilidade da informação contábil. Revista Contabilidade \& Finanças, v. 24, n. 63, p. 219-230, 2013.

VALENTE, N. T. Z. Qualidade da informação contábil na perspectiva da ciência da informação. 2014. Tese (Doutorado em Cultura e Informação) - Escola de Comunicações e Artes, Universidade de São Paulo, São Paulo, 2014.

VIEIRA, L. A. Projeto de pesquisa e monografia: O que é? Como se faz? Normas da ABNT. 3. ed. Curitiba: Ed. do autor, 2004.

Revista Ambiente Contábil - ISSN 2176-9036 - UFRN - Natal-RN. v. 10. n. 1, p. 37 - 53, jan./jun. 2018. 